\title{
Variation in groundwater manganese in Finland
}

\author{
Anne Kousa (1) Hannu Komulainen · Tarja Hatakka • Birgitta Backman • \\ Sirpa Hartikainen
}

Received: 31 January 2020/ Accepted: 16 June 2020/Published online: 3 July 2020

(C) The Author(s) 2020

\begin{abstract}
Increasing evidence has emerged that $\mathrm{Mn}$ derived from drinking water could be a health risk, especially for children. This study aimed to provide more information on the variation in Mn concentrations in well water and factors that affect manganese concentrations in groundwater in the natural environment. The geochemical data consisted of analyses of single water samples $(n=5311)$ that were taken only once and data from monitoring sites where water samples $(n=4607)$ were repeatedly taken and analyzed annually from the same wells. In addition, the well-specific results from six wells at monitoring sites were described in detail. We obtained the data on water samples from the groundwater database of Geological Survey of Finland. In single samples, Mn concentrations varied from $<0.02 \mu \mathrm{g} / \mathrm{l}$ to $5800 \mu \mathrm{g} / \mathrm{l}$
\end{abstract}

\footnotetext{
A. Kousa $(\bowtie)$

Environmental Solutions, Geological Survey of Finland, Kuopio, Finland

e-mail: anne.kousa@gtk.fi

\section{H. Komulainen}

Health Security, Environmental Health, National Institute for Health and Welfare, Kuopio, Finland

T. Hatakka $\cdot$ B. Backman

Environmental Solutions, Geological Survey of Finland,

Espoo, Finland

\section{S. Hartikainen}

Faculty of Health Sciences, School of Pharmacy,

University of Eastern Finland, Kuopio, Finland
}

in bedrock well waters and up to $6560 \mu \mathrm{g} / \mathrm{l}$ in Quaternary deposit well waters. Results from single water samples from bedrock wells and Quaternary deposit wells indicated that the dissolved oxygen content has an inverse association with the $\mathrm{Mn}$ concentration. When the dissolved oxygen $\mathrm{O}_{2}$ levels were lower, the Mn concentrations were higher. No clear association was found between the Mn concentration and the $\mathrm{pH}$ or depth of the well for single samples. Part of Mn was particle bound, because total $\mathrm{Mn}$ was higher than soluble $\mathrm{Mn}$ in most measured samples. In the monitoring survey, large variation in Mn concentrations was found in bedrock well water in Kemijärvi, 114-352 $\mu \mathrm{g} / \mathrm{l}$, and in dug well water in Hämeenkoski, 8.77-2640 $\mu \mathrm{g} / \mathrm{l}$. Seasonal and spatial variability in Mn concentrations in water samples from two bedrock wells was large at monitoring sites in northern Finland. Variability in the Mn concentrations in groundwater can be large, even in the same area. These data suggest that single measurements of the Mn concentration from a water source may not reveal the Mn status, and measurement of both the total and soluble $\mathrm{Mn}$ concentrations may be recommended.

Keywords Manganese - Groundwater - Bedrock · Quaternary deposit · Medical geology 


\section{Introduction}

Manganese $(\mathrm{Mn})$ is a naturally occurring element found ubiquitously in bedrock, soil, water, air, and plants. Manganese may also be present in the environment as a result of anthropogenic sources such as mining, industrial emissions, and landfill leaching. In groundwater and surface water sources, manganese typically occurs particularly in anaerobic conditions (WHO 2017). The main oxidation states in water are $\mathrm{Mn}(\mathrm{II})$, which is a soluble and bioavailable form, and $\mathrm{Mn}(\mathrm{IV})$, which is an insoluble form. Mn(II) usually predominates in waters at a $\mathrm{pH}$ level of 4-7. If the $\mathrm{pH}$ and redox potential of the water increase, $\mathrm{Mn}$ (II) may be oxidized to $\mathrm{Mn}(\mathrm{IV})$. The main factors contributing to the chemical composition of groundwater are geological, atmospheric, marine, anthropogenic, and seasonal factors (Lahermo et al. 1990). Geological factors contribute to the composition of groundwater through the effect of chemical water-rock interactions in aquifers (Lahermo et al. 1990). The groundwater in deep bedrock aquifers has a longer residence time and displays smaller seasonal variations than shallow aquifers (Kortelainen and Karhu 2004). Private wells have usually been dug into glacial till (soil parent material) deposits or drilled into fractured bedrock in sparsely inhabited rural areas in Finland (Lahermo et al. 1990; Korkka-Niemi 2001). High Mn concentrations in groundwater are especially found in the clay-rich western coastal areas of Finland, where acid sulfate areas prevail (Tarvainen et al. 2001). At levels exceeding $100 \mu \mathrm{g} / \mathrm{l}, \mathrm{Mn}$ in water supplies may cause an undesirable taste in drinking water and stain sanitary ware and laundry (WHO 2017). The presence of $\mathrm{Mn}$ in tap water, similarly to iron, may lead to the accumulation of deposits in the distribution system. In household water, concentrations below $100 \mu \mathrm{g} / \mathrm{l}$ are usually acceptable to consumers. At a level of $200 \mu \mathrm{g} /$ 1, manganese will often form a coating on pipes, which may slough off as a black precipitate (WHO 2017). In Finland, household water is derived from groundwater and surficial water. About $60 \%$ of water is distributed by municipal waterworks, which is derived from groundwater or artificial groundwater. $\mathrm{Mn}$ is not a major problem in public water supplies.

$\mathrm{Mn}$ is known as a neurotoxic element, but it is also an essential micronutrient required in trace amounts for human health. The general population (i.e., having no occupational exposure) may become exposed to manganese through the ingestion of food and water, the inhalation of dust, and to a lesser degree through dermal contact with air, water, and soil (ATSDR 2012). The main dietary sources of Mn are tea, nuts, whole grains, legumes, and fruits (ATSDR 2012).

Manganese concentrations in groundwater are dependent on rainfall chemistry, the dissolution of minerals from bedrock, leaching by water percolating through soil, and the residence time. Higher concentrations of $\mathrm{Mn}$ are found in acidic groundwater with a low $\mathrm{pH}$ and anaerobic conditions (Lahermo et al. 1990; IMnI 2013). Aquifer properties, such as the occurrence of peat, fine-grained sediments, or clay, the condition of the well, and anthropogenic pollution, are more pronounced contributors to the Mn concentrations in groundwater than the lithological environment (Lahermo et al. 1990).

To date, $\mathrm{Mn}$ in water has only been considered as a technical/aesthetic or cosmetic problem at the regulatory level. However, increasing evidence has emerged that $\mathrm{Mn}$ derived from drinking water could be a health risk, especially for children (Bouchard et al. 2011; Khan et al. 2011; Wasserman et al. 2011; Neal and Guilarte 2013; Oulhote et al. 2014). The risk of neurotoxic effects on children starts to increase when the concentration in drinking water exceeds $100 \mu \mathrm{g} / \mathrm{l}$ (Bouchard et al. 2011). Higher Mn levels in tap water and hair were significantly associated with lower intelligence quotient (IQ) scores among school children at the age of 6-13 years in a Canadian study (Bouchard et al. 2011). The median Mn concentration in their tap water was $34 \mu \mathrm{g} / \mathrm{l}$ (range 1-2700 $\mu \mathrm{g} / \mathrm{l}$ ). A tenfold increase in drinking water Mn concentrations was associated with a decrease of 2.4 IQ points $(95 \%$ confidence interval: -3.9 to $-0.9 ; p<0.01$ ) (Bouchard et al. 2011). This association was not found with Mn intake from food, suggesting that exposure from drinking water and food may differ (Bouchard et al. 2011). Manganese may more readily be absorbed from drinking water than when ingested via food (Health Canada 2019). Even at low levels, exposure to manganese in tap water was associated with poorer neurobehavioral performances in children (Oulhote et al. 2014). Smith et al. (2013) demonstrated a strong relationship between blood manganese and iron deficiency among children. Children with iron deficiency anemia may be at risk of manganese toxicity (Smith et al. 2013). 
Guidelines for $\mathrm{Mn}$ in drinking/household water vary between countries. In Finland, there is no healthbased chemical quality standard requirement for $\mathrm{Mn}$ in household water. The quality recommendation, based on technical/aesthetic effects, is below $50 \mu \mathrm{g} / \mathrm{l}$, and the threshold limit is $100 \mu \mathrm{g} / \mathrm{l}$ for small units or households using private wells (STM 1352/2015, STM 401/2001). The health-based limit value for Mn set by the World Health Organization is $400 \mu \mathrm{g} / \mathrm{l}$, based on an upper tolerable intake (WHO 2011). According to WHO, the calculated health-based value is well above concentrations of Mn normally found in drinking water. Therefore, it was not considered necessary to derive a formal guideline value in the most recent evaluation (WHO 2011).

A good understanding of the natural variability in the concentrations of inorganic elements, including $\mathrm{Mn}$, in private water supplies is important to ensure safe potable water for those residents whose water source is solely a private well (Ander et al. 2016). To the best of our knowledge, studies on factors associated with the natural concentrations of $\mathrm{Mn}$ in groundwater from the human health risk perspective are scarce. Therefore, a more detailed evaluation of the spatial and temporal variation in Mn concentrations in groundwater is needed for reliable intake and health risk assessment. The purpose of this paper is to provide further information on the factors that affect manganese concentrations in groundwater in the natural environment. This article is mainly based on data from a project published in Archive report 95/2016 of the Geological Survey of Finland by Kousa et al. (2017, in Finnish).

\section{Material and methods}

The Precambrian bedrock of Finland is composed of igneous and metamorphic rocks (Bedrock of Finland DigiKP, 2019). The bedrock is overlain by Quaternary deposits, a glacial overburden with an average thickness of about seven meters. Quaternary deposits were formed by several glaciations during the last two to three million years. These surficial loose materials are composed of sand, gravel, clay, and silts, which are extensively covered by recent peat layers (Koljonen and Tanskanen 1992). The studied dataset contains analyses of groundwater samples. However, water samples were taken from different kinds of wells.
Water samples of springs, captured springs, and dug wells are often taken directly from the well or the waterbed. Thus, in these water samples, the structure of the captured spring or well might have an effect on the water quality. Water samples from bedrock wells are usually taken from a tap (drinking water/tap water). Therefore, the groundwater quality of these samples may be affected by the water system. In these cases, water flows through water pipes as well as a pressure tank, and these might affect the metal concentrations in the water. A detailed examination of the bedrock geology was not conducted for the wells in the present study.

In rural areas, water supplies consist of wells drilled into bedrock, dug wells, springs, captured springs, and sometimes groundwater tubes and wells drilled into overburden discharging household water from Quaternary deposits. Dug wells, which are often located in glacial till areas, represent the most common well type in rural areas (Backman 2004; Korkka-Niemi 2001). Formerly, dug wells were lined with wood or stones, but nowadays they are mainly constructed of concrete rings (Korkka-Niemi 2001). Springs and captured springs are natural sources of water flowing from an aquifer to the earth's surface. Captured springs are lined with a shallow wooden casing or concrete ring (Korkka-Niemi 2001). Drilled wells obtain water from either overburden or bedrock aquifers. Wells drilled into overburden are constructed into overburden aquifers, i.e., geological materials above bedrock (Simpson 2015). Quaternary deposit wells are usually shallow, only $3-5 \mathrm{~m}$ in depth, and $80-120 \mathrm{~cm}$ in diameter. Springs and shallow dug wells a few meters in depth represent shallow groundwater percolating through the ground surface (Tarvainen et al. 2001). Likewise, wells drilled into fractured bedrock are common. These wells are generally $40-80 \mathrm{~m}$ deep and $110 \mathrm{~mm}$ in diameter. Their average yield is 500-2000 L per hour (Korkka-Niemi 2001; Lahermo et al. 1990). Groundwater observation tubes, usually made of PVC or PEH plastic, are drilled into overburden to monitor groundwater quality.

This study aimed to clarify the variability in $\mathrm{Mn}$ concentrations and the relationship with other geochemical factors of groundwater and properties of water sources in Finland, utilizing data collected by GTK during 1992-2013. Two datasets of water sample analyses were available: single samples taken once from wells and samples taken repeatedly from 
the same wells at monitoring sites. Data on bedrock wells and wells in Quaternary deposits (dug wells, springs, captured springs, and tube wells) were included in this study. All these water samples had been analyzed using ICP-MS/AES with a detection limit of $0.02 \mu \mathrm{g} / \mathrm{l}$ for $\mathrm{Mn}$. The groundwater data used in this study consisted of water samples analyzed after 1991, because the analysis methods changed and ICPMS/AES was solely in use after that. Analytical data before 1992 were not comparable with ICP-MS/AES analyses, because the detection limits differed. The $\mathrm{pH}$ values and the concentrations of dissolved oxygen $\left(\mathrm{O}_{2}\right)$ were measured in the field in conjunction with water sampling by using oxygen and $\mathrm{pH}$ meters (e.g., WTW Oxi 320/330 and WTW Multiline P3 pH/LF, respectively). The samples were taken by experienced and/or certified personnel. The quality of sampling was assured by including blank samples and/or duplicate samples in the analysis. Water samples were analyzed in accredited laboratories, and their analytical methods were accredited or were based on standards. The accredited testing laboratories enforce their own customary quality assurance methods. The Kolmogorov-Smirnov test was used to verify the normality of the distribution of groups classified according to Mn concentrations. Statistical differences between the groups were tested using the nonparametric Kruskal-Wallis test and ANOVA, and correlations between variables were determined by twotailed Spearman correlation. Statistical analyses were conducted, and graphics were produced using IBM ${ }^{\circledR}$ SPSS ${ }^{\circledR}$ Statistics versions 24 and 25 and map presentations using ArcMap 10.3 software.

Single water samples were taken only once from each well during 1992-2013. We obtained data on single water samples from the groundwater database of the Geological Survey of Finland (GTK). The total number of single water samples was 5311, including samples from 2383 bedrock wells and 2928 Quaternary deposit wells in Finland. The data were classified into four groups based on the Mn concentrations according to the Finnish national quality recommendations and the guidelines of WHO for statistical analyses (STM 1352/2015, STM 401/2001, WHO 2011): < $50 \mu \mathrm{g} / \mathrm{l}, 51-100 \mu \mathrm{g} / \mathrm{l}, 101-400 \mu \mathrm{g} / \mathrm{l}$, and $>$ $400 \mu \mathrm{g} / \mathrm{l}$.

Water samples from monitoring sites were repeatedly taken and analyzed annually from the same wells during 1992-2009. We obtained data on monitoring sites from the groundwater database of the Geological Survey of Finland (GTK). GTK has conducted groundwater monitoring in southern Finland since 1969 (Backman 1993). The monitoring wells are mostly located in southern Finland and to a lesser extent in the other parts of the country (Fig. 1). Since 1993, monitoring sites have expanded to cover virtually the whole country (Backman et al. 1999; Backman 2004). The acid soil areas from the western coast of Finland have not been included in the monitoring sites of GTK. The latest water samples included in this study were taken in 2009. The original aim of the groundwater monitoring survey conducted by GTK was to investigate the short- and long-term effects of geology and human activities on groundwater quality. In this study, the total number of water samples was 4607 from 138 wells at monitoring sites, consisting of 380 water samples from bedrock wells $(n=22)$ and 4227 samples from Quaternary deposit wells $(n=116)$. Data on the monitoring sites selected in this study covered such a long period that the seasonal and annual variations could be detected. Annual variations in rainfall and temperature have had an effect on groundwater formation and levels and therefore also on the quality of groundwater. The representation of different geological environments and well types was also taken into consideration when monitoring sites were selected.

\section{Results and discussion}

The Finnish national maximum recommendation for $\mathrm{Mn}$ in drinking water is $<50 \mu \mathrm{g} / \mathrm{l}$ and for small units and private wells $<100 \mu \mathrm{g} / \mathrm{l}$ (STM 1352/2015, STM $401 / 2001$ ). In single water samples, about $41 \%$ of single water samples from wells drilled in bedrock and $17 \%$ of those from wells in Quaternary deposits exceeded the Finnish national recommendation for $\mathrm{Mn}$. Twenty-eight per cent of waters in bedrock wells and $11 \%$ in Quaternary deposit wells exceeded the national recommendation for small units and private wells. In monitoring sites, the maximum recommendation for small units was exceeded in $41.5 \%$ of bedrock well water samples and $5.1 \%$ of Quaternary well water samples. Mn concentrations in water samples from bedrock wells and Quaternary deposit wells have been presented separately (Table 1), because the geochemistry of groundwater varies 


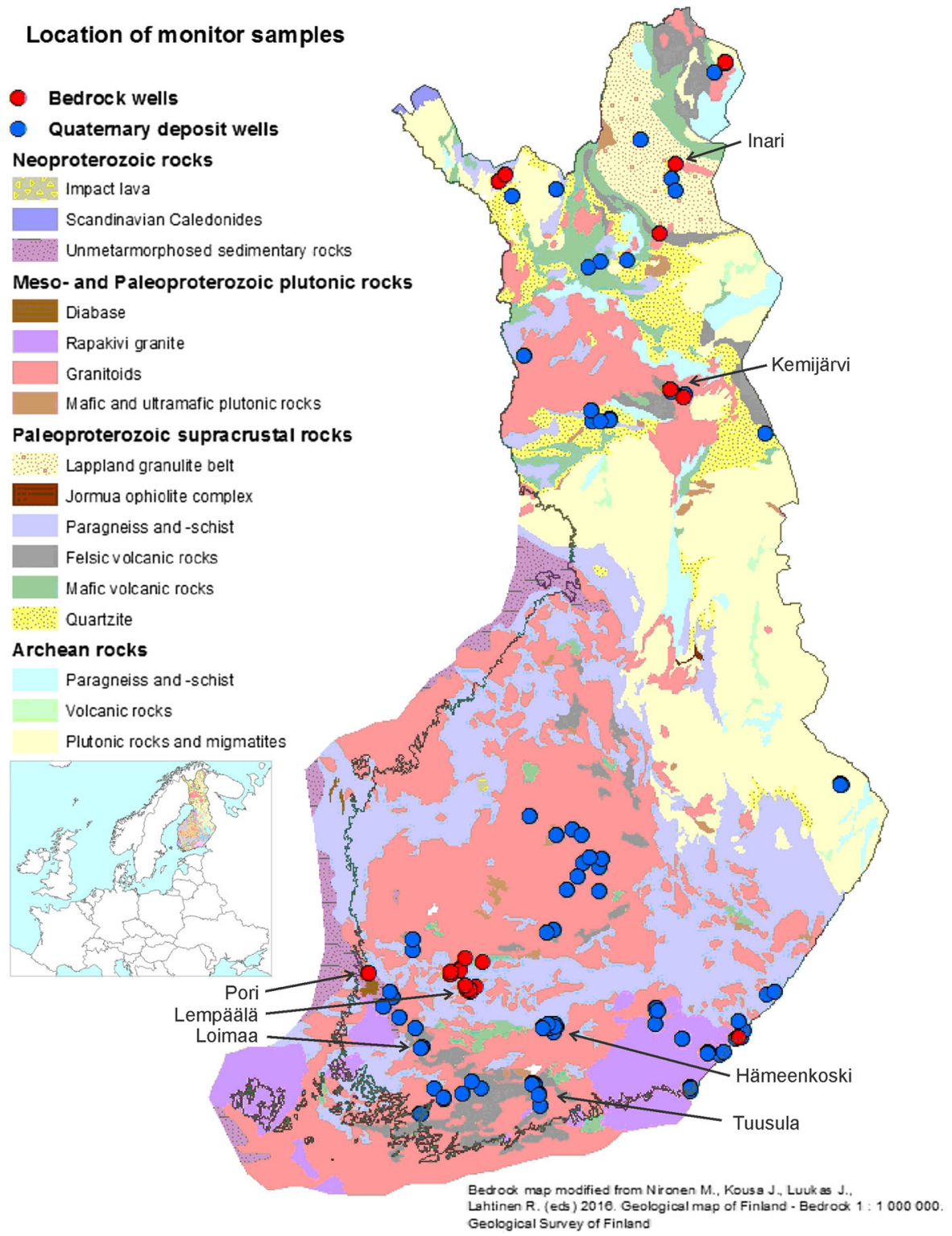

Fig. 1 Locations of sampled monitoring sites and index map

between these well types. The wells in Quaternary deposits were mainly dug wells, springs, captured springs, and tubes. The median Mn concentration was $2.31 \mu \mathrm{g} / \mathrm{l}$ in water from all wells in Quaternary deposits and $26.8 \mu \mathrm{g} / \mathrm{l}$ in water from bedrock wells. In the results of the "One Thousand Wells" groundwater quality mapping project in Finland in 1999, the median Mn concentration was $4.35 \mu \mathrm{g} / \mathrm{l}$ in well waters from Quaternary deposits and $16.3 \mu \mathrm{g} / \mathrm{l}$ in wells drilled in bedrock (Lahermo et al. 2002). 
Table 1 Minimum, median, and maximum Mn concentrations ( $\mu \mathrm{g} / \mathrm{l})$ in combined data of single water samples and samples from monitoring sites according to the well type in Finland in 1992-2013

\begin{tabular}{|c|c|c|c|c|}
\hline Groundwater Mn $\mu \mathrm{g} / \mathrm{l}$ & Minimum & Median & Maximum & Number of samples \\
\hline \multicolumn{5}{|l|}{ Quaternary deposit } \\
\hline Springs & $<0.02$ & 0.56 & 3760 & 2195 \\
\hline Captured springs & $<0.02$ & 1.59 & 2530 & 657 \\
\hline Groundwater tubes & 0.08 & 0.97 & 429 & 1242 \\
\hline Tube wells in aquifers covered by clay & $<0.02$ & 2.49 & 6560 & 241 \\
\hline Dug wells & 0.02 & 5.93 & 5330 & 2771 \\
\hline \multicolumn{5}{|l|}{ Bedrock } \\
\hline Drilled wells & $<0.02$ & 26.8 & 5800 & 2671 \\
\hline
\end{tabular}

Bedrock wells: single water samples

A total of 2383 wells drilled into bedrock were included in this study. Anomalously high Mn concentrations in bedrock well water were uniformly distributed in Finland, as shown in Fig. 2. The range of $\mathrm{Mn}$ concentrations in waters of wells drilled in bedrock was large, $<0.03-5800 \mu \mathrm{g} / \mathrm{l}$. Mn correlated significantly with $\mathrm{Fe}(r=0.624 * *, p<0.01)$. The statistics for $\mathrm{Mn}$, iron $(\mathrm{Fe}), \mathrm{pH}$, and oxygen $\left(\mathrm{O}_{2}\right)$ content are presented in Table 2.

Statistically significant associations were found between $\mathrm{Mn}$ and $\mathrm{Fe}(p=0.00)$ and between $\mathrm{Mn}$ and $\mathrm{O}_{2}(p=0.00)$ when the data were compared for groups classified according to the Mn concentration (Table 3 ). The Fe concentration increased accordingly with the Mn levels, the median being $0.75 \mathrm{mg} / \mathrm{l}(750 \mu \mathrm{g} / \mathrm{l})$ when the $\mathrm{Mn}$ concentration was over $400 \mu \mathrm{g} / \mathrm{l}$. Overall, the median concentration of $\mathrm{Fe}$ was $0.04 \mathrm{mg} / \mathrm{l}(40 \mu \mathrm{g} / \mathrm{l})$ in this dataset. The Finnish quality recommendation for $\mathrm{Fe}$ is below $200 \mu \mathrm{g} / \mathrm{l}$ (STM 2015). The content of dissolved oxygen decreased as a function of increasing Mn concentration up to a $\mathrm{Mn}$ concentration $400 \mu \mathrm{g} / \mathrm{l}$, being $35.7 \%$ at lowest. In the highest class of $\mathrm{Mn}$, the $\mathrm{pH}$ was lowest, but the difference between the groups was not statistically significant $(p=0.69)$ (Table 3).

The total number of high Mn concentrations, exceeding $100 \mu \mathrm{g} / \mathrm{l}$, was 592. Within the depth categories of wells, the highest proportion of high concentrations $(34.4 \%)$ was found in wells with a depth of 20-40 m (Fig. 3). However, the proportion was rather similar $(24.1-34.4 \%)$ in all depth categories, irrespective of the depth of the bedrock well

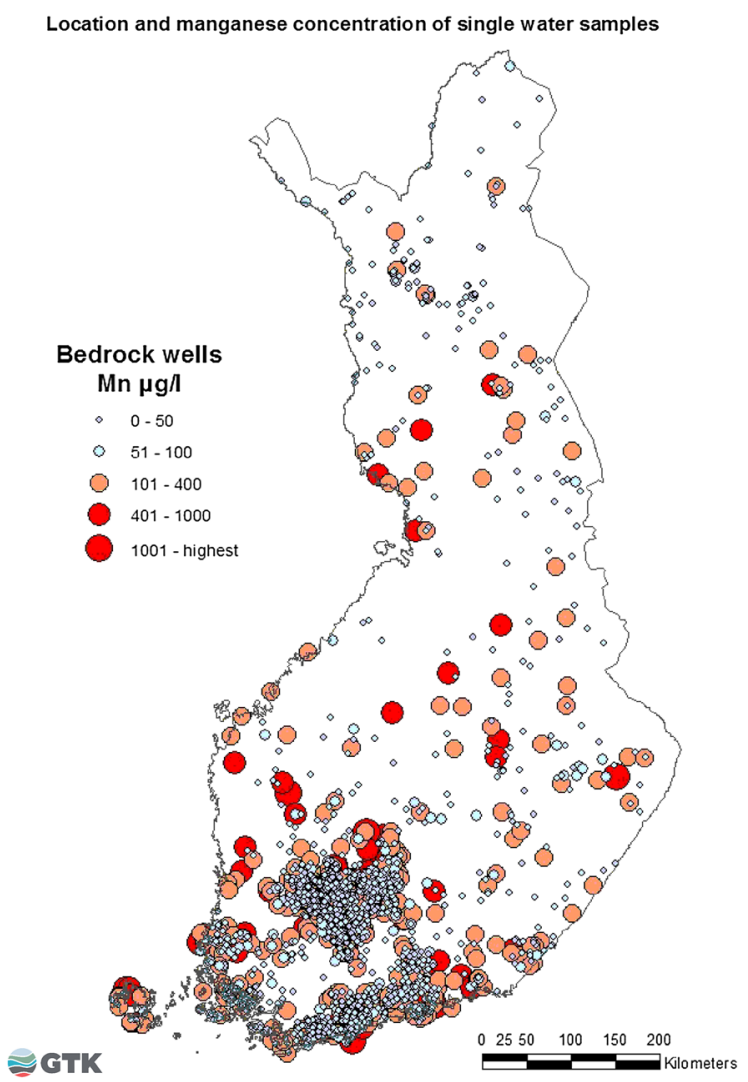

Fig. 2 Locations and distribution of Mn concentrations in single water samples from bedrock wells in 1992-2013

( $p=0.537)$. Prediction maps of Mn concentrations indicated that the elevated level of $\mathrm{Mn}$ in the groundwater of North Carolina in the USA was not attributable to the bedrock geology or well depth (Johnson et al. 2018). Likewise, in our study, high Mn 
Table 2 Median, mean, standard deviation, maximum, and $2 \%$ and $98 \%$ percentiles for manganese $(\mathrm{Mn})$, iron $(\mathrm{Fe}), \mathrm{pH}$, and oxygen $\left(\mathrm{O}_{2}\right)$ content in single water samples from wells drilled in bedrock

\begin{tabular}{lllll}
\hline Bedrock drilled wells & $\mathrm{Mn} \mu \mathrm{g} / \mathrm{l}$ & $\mathrm{Fe} \mathrm{mg/l}$ & $\mathrm{pH}$ (field) & $\mathrm{O}_{2} \%$ (field) \\
\hline $2 \%$ & 0.25 & $<0.02$ & 5.8 & 8.5 \\
Median & 28.4 & 0.04 & 7.30 & 47.6 \\
Mean & 100 & 0.46 & 7.27 & 49.1 \\
$\mathrm{SD}$ & 224 & 1.75 & 0.77 & 26.2 \\
$98 \%$ & 638 & 5.2 & 8.84 & 104 \\
Maximum & 5800 & 39.9 & 9.50 & 143 \\
$N$ & 2291 & 2291 & 1331 & 1134 \\
\hline
\end{tabular}

Table 3 Median, mean, standard deviation (SD), and range of single water samples (n) for $\mathrm{Fe}, \mathrm{pH}$, and $\mathrm{O}_{2}$ in waters of bedrock wells according to the $\mathrm{Mn}$ concentration category

\begin{tabular}{|c|c|c|c|}
\hline $\mathrm{Mn}$ & $\mathrm{Fe} m g / 1^{\mathrm{a}}$ & $\mathrm{pH}$ (field) & $\mathrm{O}_{2} \%$ (field) $^{\mathrm{a}}$ \\
\hline \multicolumn{4}{|l|}{$<50 \mu \mathrm{g} / 1$} \\
\hline Median & $<0.03$ & 7.30 & 56.2 \\
\hline Mean & 0.06 & 7.27 & 56.0 \\
\hline SD & 0.15 & 0.88 & 26.3 \\
\hline Range & $<0.03-2.63$ & $5.20-9.50$ & $0.0-144$ \\
\hline$n$ & 1346 & 792 & 666 \\
\hline \multicolumn{4}{|c|}{$51-100 \mu \mathrm{g} / 1$} \\
\hline Median & 0.09 & 7.50 & 39.2 \\
\hline Mean & 0.34 & 7.36 & 40.0 \\
\hline SD & 0.87 & 0.60 & 23.2 \\
\hline Range & $<0.03-7.86$ & $5.20-8.80$ & $0.0-126$ \\
\hline$n$ & 293 & 166 & 141 \\
\hline \multicolumn{4}{|c|}{$101-400 \mu \mathrm{g} / 1$} \\
\hline Median & 0.24 & 7.30 & 35.7 \\
\hline Mean & 1.11 & 7.26 & 39.1 \\
\hline SD & 2.45 & 0.56 & 22.8 \\
\hline Range & $<0.03-28.5$ & $5.40-9.40$ & $6.10-124$ \\
\hline$n$ & 534 & 297 & 262 \\
\hline \multicolumn{4}{|c|}{$>400 \mu \mathrm{g} / \mathrm{l}$} \\
\hline Median & 0.75 & 7.20 & 39.2 \\
\hline Mean & 2.32 & 7.16 & 38.1 \\
\hline SD & 4.97 & 0.46 & 20.1 \\
\hline Range & $<0.03-39.9$ & $6.20-9.10$ & $9.10-116$ \\
\hline$n$ & 113 & 71 & 61 \\
\hline
\end{tabular}

${ }^{\mathrm{a}}$ Kruskal-Wallis test, $p=0.00$

concentrations were found in all depth classes of the bedrock wells studied.

The data indicated that the dissolved oxygen content has an inverse association with Mn concentrations. In the presence of low $\mathrm{O}_{2}$ levels, the Mn concentrations

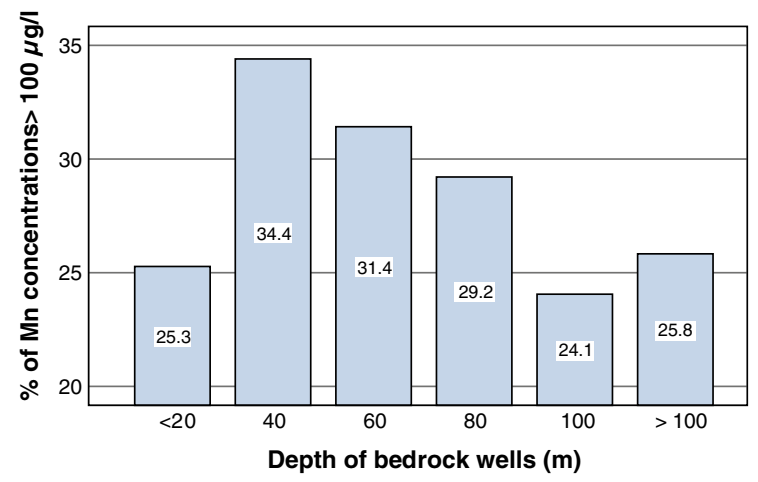

Fig. 3 The percentage of single water samples with a Mn concentration above $100 \mu \mathrm{g} / \mathrm{l}$ in each depth class of bedrock wells

were higher. Moreover, $\mathrm{Mn}$ was associated with the $\mathrm{Fe}$ concentration in water, and high concentrations of both were concomitantly detected. No clear association was found between the $\mathrm{Mn}$ concentration and $\mathrm{pH}$ in single water samples from bedrock wells.

High Mn concentrations were more often detectable in water from bedrock wells than Quaternary deposit wells. The chemical composition of bedrock water differs from that of shallow groundwater. The retention time and aquifer type have a clear effect on the metal concentrations, including $\mathrm{Mn}$, in groundwater. A high $\mathrm{Mn}$ concentration is a result of a long retention time of water passing through geological materials, as well as the reducing conditions prevailing in bedrock wells. This process mobilizes manganese in the soluble Mn(II) form (Korkka-Niemi 2001). Therefore, bedrock groundwater often more contains dissolved elements. In this study, the highest Mn concentrations ( $>100 \mu \mathrm{g} / \mathrm{l})$ in groundwater from drilled bedrock wells were recorded in those wells located in metamorphic schist and paragneiss areas originating from both sedimentary and volcanic sources in the southern coastal area, and in similar 
geological areas in central and northern Finland. Furthermore, high Mn concentrations were found in rapakivi granite areas in southern Finland. However, the detailed bedrock geology of the wells was not examined in this study.

Bedrock wells: monitoring survey

Altogether, 380 analyses from 22 bedrock wells in the monitoring survey were included in this study. High Mn concentrations, exceeding $100 \mu \mathrm{g} / \mathrm{l}$, were found during the monitoring period in four wells. Two of these were located in northern Finland, in the municipalities of Kemijärvi and Inari, which were monitored from 1993 to 2009. The other two wells were located in the southern part of the country: one in the municipality of Lempäälä, monitored from April to August 2005, and the other in the city of Pori, monitored from 1993-2000 (Fig. 1).

In Kemijärvi, the bedrock of the study area is composed of Paleoproterozoic granites and variously migmatized granitoid units (Bedrock of Finland DigiKP; Nironen et al. 2016). The sampled well was drilled through a glacial esker. The depth of the well was $83 \mathrm{~m}$, and the thickness of the overlay material was $16 \mathrm{~m}$. The number of water samples was 51 . The

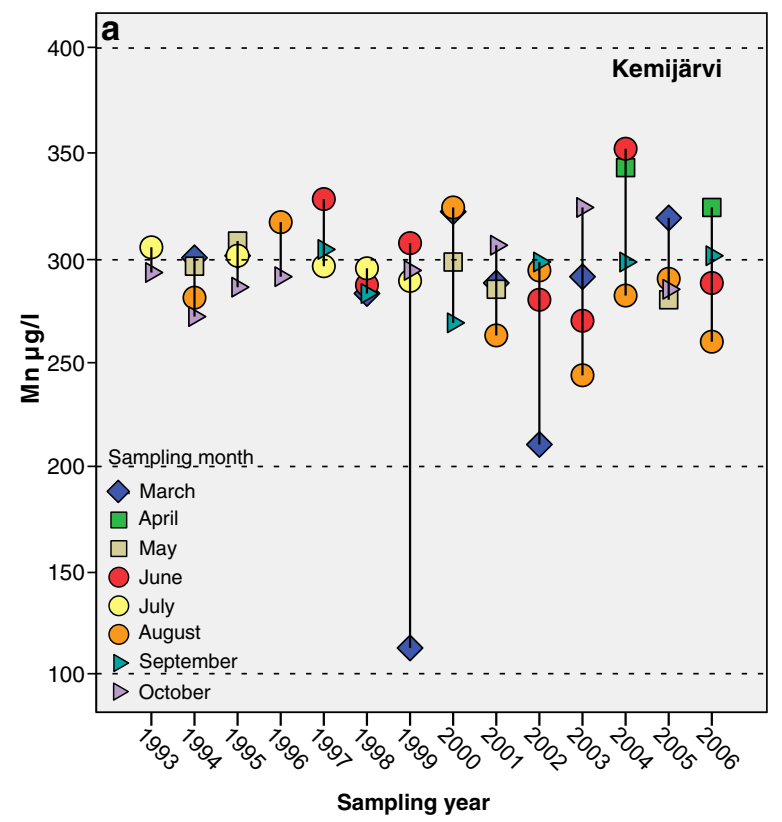

concentrations of all other elements in the well water except Mn were mainly very low, even below the detection limits. Only the Mn concentration was above the current drinking water regulation of $100 \mu \mathrm{g} / \mathrm{l}$. The annual variability in $\mathrm{Mn}$ concentrations in the well water was between 114 and $352 \mu \mathrm{g} / \mathrm{l}$ in 1993-2006. The variability was lower in the first years of monitoring, from 1993-1998. The largest variation was found in 1999, when the lowest Mn concentration was $114 \mu \mathrm{g} / \mathrm{l}$ in March and the highest was $307 \mu \mathrm{g} / \mathrm{l}$ in June. According to the $\mathrm{SiO}_{2}$ concentrations in the same sample, the retention time of the water was clearly shorter than it used to be at this monitoring site. This, as well as the elevated oxygen concentration in the water, may explain the low Mn concentration in 1999. However, the reason for the freshwater pulse in the well is unknown. In general, the variability was greater after 1999 than in earlier years at the Kemijärvi monitoring site (Fig. 4a).

At Inari, the bedrock of the study area is composed of granate-cordierite-rich paragneiss of the Lapland granulite complex (Bedrock of Finland DigiKP; Nironen et al. 2016). The depth of the well was $76 \mathrm{~m}$, and the number of water samples was 51 . The lowest $\mathrm{Mn}$ concentrations were generally found in samples taken in March (Fig. 4b). The largest

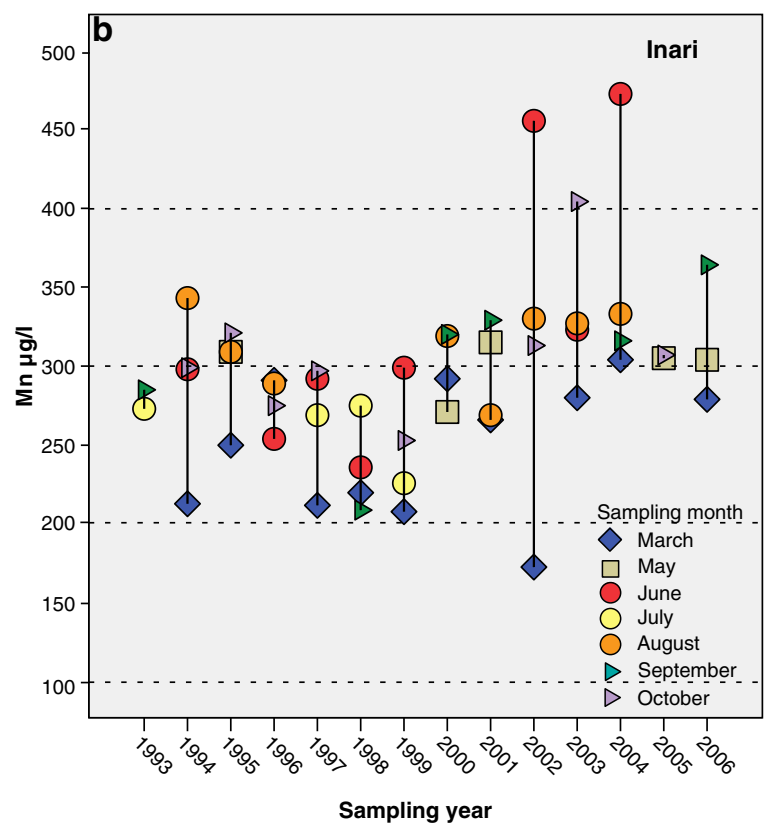

Fig. 4 a and b Annual and monthly variation in manganese concentrations in water from bedrock wells at the monitoring sites in Kemijärvi $(\min =114, \max =352 \mu \mathrm{g} / \mathrm{l})$ and Inari $(\min =173, \max =472 \mu \mathrm{g} / \mathrm{l})$, northern Finland, in $1993-2006$ 
variation was between the $\mathrm{Mn}$ concentration of $173 \mu \mathrm{g} / 1$ recorded in March 2002 and $472 \mu \mathrm{g} / 1$ in June 2004. The concentrations of some other elements were notably high in this well water. For example, the concentrations of strontium (median $562 \mu \mathrm{g} / \mathrm{l}$ ) were tenfold higher than at some other monitoring sites in northern Finland (Hatakka et al. 2007; Backman et al. 1999).

In general, seasonal variation was not evident in the bedrock wells. However, according to the results from these bedrock wells located at monitoring sites, Mn concentrations in two wells displayed clear annual and seasonal variation. High $\mathrm{Mn}$ concentrations and considerable annual and monthly variation were found in the waters of wells in both Kemijärvi and Inari in the course of the monitoring. In both wells, Mn concentrations in water samples taken in spring and summer were higher than in samples taken in winter. In Finland, precipitation is usually lower and evaporation is higher in summer, and the amount of water is therefore lower and the level of the groundwater table is low. This could partly explain the variability in Mn concentrations in these two wells.

The bedrock well in Pori was a 600-m-deep artesian well drilled by GTK. In an artesian well, the water rises to the surface under its own pressure. GTK drilled this well in a Mesoproterozoic sandstone area to intersect the Satakunta sandstone formation and reach the underlying bedrock of the Pirkanmaa migmatite suite (Bedrock of Finland, DigiKP; Nironen et al. 2016). However, the bottom of the sandstone deposit was not reached, and the well was thus entirely situated in sandstone. Annual or monthly variation (in 1994) in Mn concentrations was not very large, being between 119-135 $\mu \mathrm{g} / \mathrm{l}$ (Fig. 5).

The bedrock well in Lempäälä was located in the unit of the Pirkanmaa migmatite suite. The bedrock of the Lempäälä area mainly consists of mica schist and mica gneiss, with mafic metavolcanic rock interlayers and plutonic intrusions such as granodiorites and granites (Bedrock of Finland, DigiKP; Nironen et al. 2016). The quality of the bedrock well water was monitored from April to August in 2005 by taking 18 water samples and 3 reference samples. The Mn concentration fluctuated between $109 \mu \mathrm{g} / \mathrm{l}$ and $164 \mu \mathrm{g} / \mathrm{l}$ over the five-month period in 2005 (Fig. 6). Detailed information on the pumping volume from wells is not generally available, but in this case, it was possible to roughly estimate the historical water

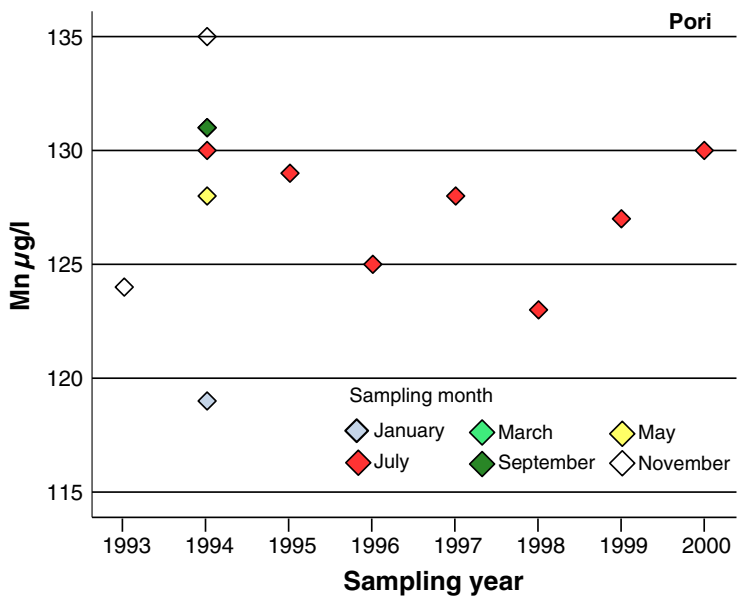

Fig. 5 Annual and monthly variation (1994) in the Mn concentration of water from an artesian bedrock well at the Pori monitoring site $(\min =119 \mu \mathrm{g} / \mathrm{l}, \quad \max =135 \mu \mathrm{g} / \mathrm{l})$ in southern Finland between 1993 and 2000

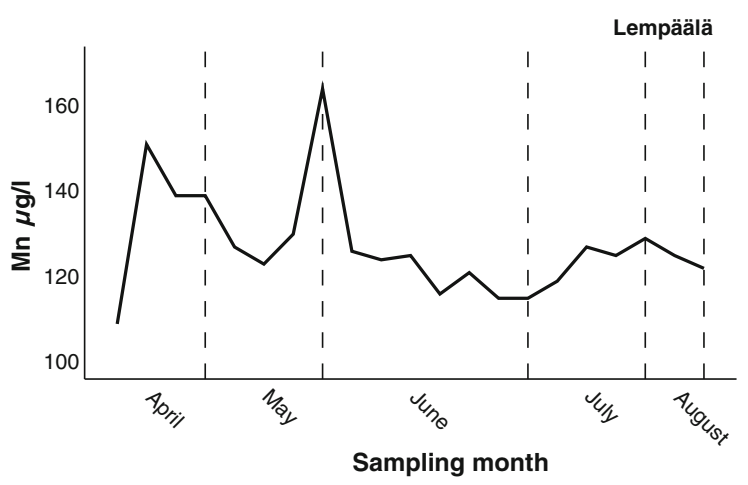

Fig. 6 The variation in Mn concentrations in bedrock well water during spring and summer 2005 at the Lempäälä monitoring site $(\min =109 \mu \mathrm{g} / \mathrm{l}, \max =164 \mu \mathrm{g} / \mathrm{l})$

consumption based on information received from the well owners. The well water was used by a market garden. The variability in the Mn concentration of the water was quite low, despite heavy pumping. At the beginning of the test in April, the pumped water volume was low, being $4.1 \mathrm{~m}^{3} /$ month. Later, the pumped water volume increased (May: $5.6 \mathrm{~m}^{3} / \mathrm{month}$; June: $263 \mathrm{~m}^{3} /$ month; July: $228 \mathrm{~m}^{3} /$ month; and August: $199 \mathrm{~m}^{3} / \mathrm{month}$ ) (Backman et al. 2006). The depth of the well was unknown, but the composition of the water corresponded to a long retention time, indicating that the well was deep.

The cumulative frequency distributions of $\mathrm{Mn}$ concentrations in waters from four wells drilled into 


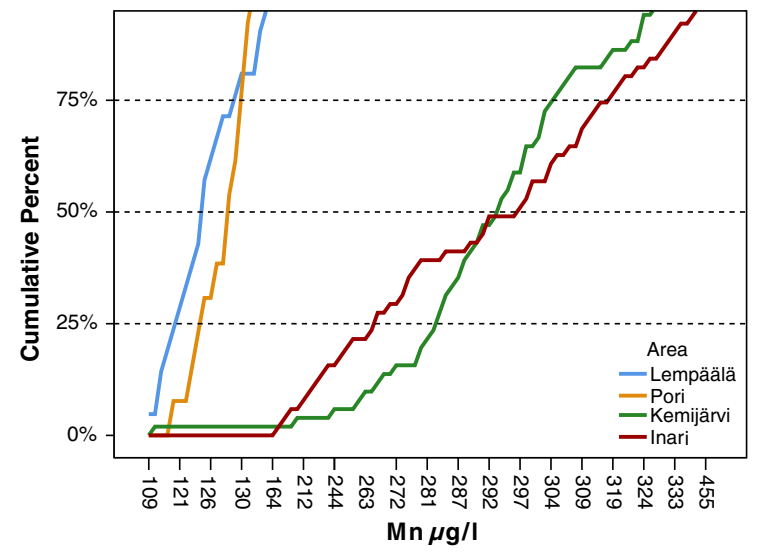

Fig. 7 The cumulative percent distribution of manganese concentrations in water for each bedrock well in which the concentration exceeded $100 \mu \mathrm{g} / \mathrm{l}$ at four monitoring sites in southern and northern Finland in 1992-2006

the bedrock in the different parts of Finland are illustrated in Fig. 7. Mn concentrations in bedrock wells at both Lempäälä and Pori in southern Finland were quite stable during the follow-up, as seen in the sharp cumulative curves (Fig. 7). The $50^{\text {th }}$ percentiles of the Mn concentrations at Lempäälä and Pori were $125 \mu \mathrm{g} / \mathrm{l}$ and $128 \mu \mathrm{g} / \mathrm{l}$, respectively. The flat cumulative curves illustrate that the Mn concentrations were higher and the range larger in both wells in northern Finland, at Kemijärvi and Inari. The $50^{\text {th }}$ percentiles of the Mn concentrations were $294 \mu \mathrm{g} / \mathrm{l}$ and $297 \mu \mathrm{g} / \mathrm{l}$, respectively (Fig. 7). However, the maximum $\mathrm{Mn}$ levels in waters of the other bedrock wells in the same municipalities, Kemijärvi and Inari in northern Finland, were under the maximum quality recommendation of $50 \mu \mathrm{g} / \mathrm{l}$ for $\mathrm{Mn}$.

Spatial variability between areas in northern and southern parts of the country may be associated with different atmospheric conditions (e.g., meltwater from snow) and geological factors such as the lithological composition of the aquifer material and residence time of the water. Taken together, these detailed data suggest that Mn levels may vary in well waters, and analysis of the Mn concentration in a single sample from a well may not reveal the true average Mn level in the water.

Quaternary deposit wells: single water samples

Analyses of 2928 single water samples taken after 1992 from wells in Quaternary deposits were included in this study. Anomalous Mn concentrations in groundwater were uniformly distributed across the country (Fig. 8). Statistically significant correlations were found between $\mathrm{Mn}$ and Co $\left(r=0.655^{* *}\right.$, $p<0.01)$ and between $\mathrm{Mn}$ and $\mathrm{Fe}\left(r=0.566^{* *}\right)$. Seventeen percent of waters in Quaternary deposit wells exceeded the Finnish national quality recommendation of $<50 \mathrm{~g} / \mathrm{l}$ for Mn (STM 1352/2015). Eleven percent exceeded $100 \mu \mathrm{g} / \mathrm{l}$, the maximum recommendation for $\mathrm{Mn}$ in small units and private wells (STM 401/2001), and 3\% exceeded $400 \mu \mathrm{g} / \mathrm{l}$, the health-based limit value presented by WHO (2011). The lowest median concentration of $\mathrm{Mn}, 0.98 \mu \mathrm{g} / \mathrm{l}$, was detected in springs, while the highest median was in tube wells drilled in Quaternary deposits, being $49.1 \mu \mathrm{g} / \mathrm{l}$ (Table 4).

The highest medians of Mn and Fe concentrations were recorded in tube wells drilled in Quaternary deposits $(p=0.00)$. The most acidic well water was found in captured springs (median $\mathrm{pH}$ 6.10), while the

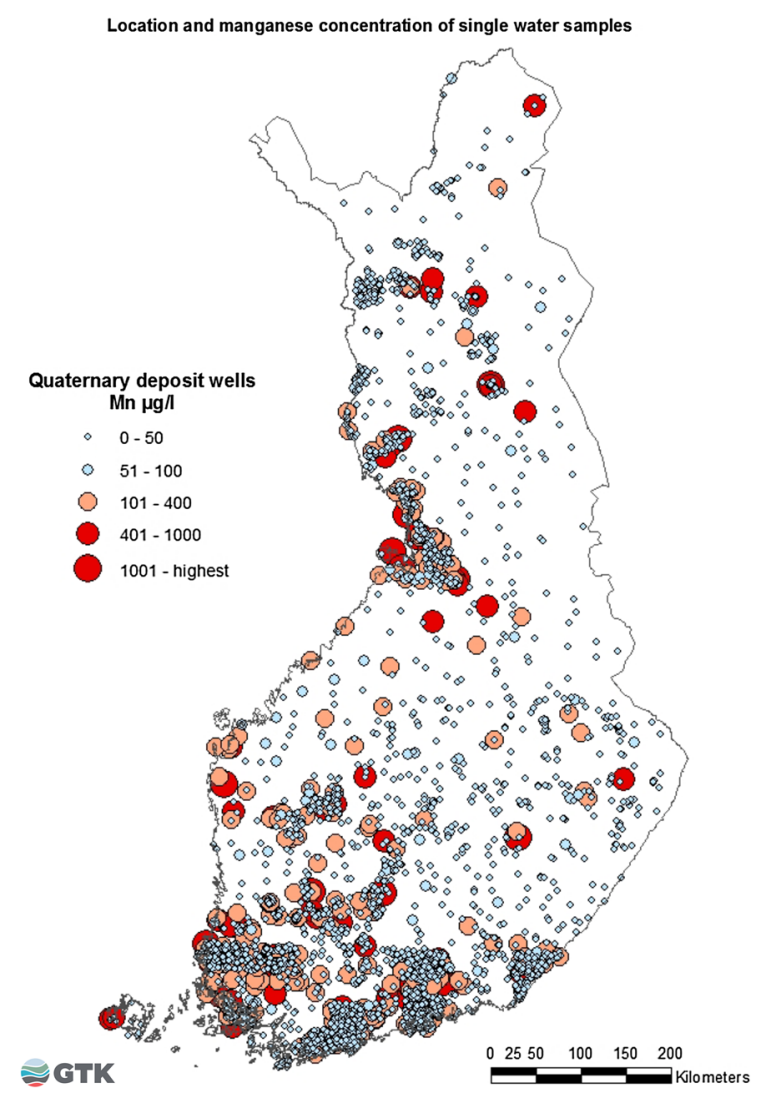

Fig. 8 Sampling locations and distribution of Mn concentrations in water samples from Quaternary deposit wells in 1992-2009 
Table 4 Median, mean, standard deviation, maximum, and $2 \%$ and $98 \%$ percentiles for manganese (Mn), iron (Fe), acidity (pH), and oxygen $\left(\mathrm{O}_{2}\right)$ in single water samples from Quaternary deposit wells

\begin{tabular}{|c|c|c|c|c|}
\hline Well type & $\mathrm{Mn} \mu \mathrm{g} / \mathrm{l}^{\mathrm{a}}$ & $\mathrm{Fe} \mathrm{mg} / \mathrm{l}^{\mathrm{a}}$ & $\mathrm{pH}(\text { field })^{\mathrm{b}}$ & $\mathrm{O}_{2} \%(\text { field })^{\mathrm{b}}$ \\
\hline \multicolumn{5}{|l|}{ Springs } \\
\hline $2 \%$ & 0,02 & $<0.02$ & 5.2 & 23.0 \\
\hline Median & 0.98 & 0.03 & 6.60 & 84.5 \\
\hline Mean & 24.9 & 0.21 & 6.60 & 85.4 \\
\hline SD & 153 & 0.99 & 0.78 & 29.6 \\
\hline $98 \%$ & 292 & 1.78 & 8.3 & 146 \\
\hline Max & 2920 & 11.6 & 9.00 & 156 \\
\hline$n$ & 530 & 530 & 505 & 394 \\
\hline \multicolumn{5}{|c|}{ Captured springs } \\
\hline $2 \%$ & 0.05 & $<0.02$ & 5.2 & 8.18 \\
\hline Median & 2.70 & 0.03 & 6.10 & 75.4 \\
\hline Mean & 31.1 & 0.12 & 6.16 & 76.2 \\
\hline SD & 163 & 0.44 & 0.52 & 32.5 \\
\hline $98 \%$ & 388 & 1.46 & 7.4 & 145 \\
\hline Max & 2530 & 5.27 & 8.50 & 156 \\
\hline$n$ & 318 & 318 & 309 & 281 \\
\hline \multicolumn{5}{|l|}{ Dug wells } \\
\hline $2 \%$ & 0.41 & $<0.02$ & 5.4 & 8.77 \\
\hline Median & 8.23 & 0.04 & 6.30 & 64.0 \\
\hline Mean & 58.2 & 0.22 & 6.36 & 64.7 \\
\hline SD & 223 & 1.09 & 0.54 & 30.1 \\
\hline $98 \%$ & 510 & 1.63 & 7.6 & 131 \\
\hline Max & 5330 & 31.1 & 9.00 & 343 \\
\hline$n$ & 1931 & 1930 & 1686 & 1533 \\
\hline \multicolumn{5}{|l|}{ Tube wells } \\
\hline $2 \%$ & $<0.02$ & $<0.02$ & 5.46 & 5.37 \\
\hline Median & 49,1 & 0.08 & 7.00 & 38.2 \\
\hline Mean & 468 & 5.29 & 6.96 & 47.6 \\
\hline SD & 1153 & 20.7 & 0.59 & 29.6 \\
\hline $98 \%$ & 5710 & 121 & 8.02 & 116 \\
\hline Max & 6560 & 133 & 8.20 & 133 \\
\hline$n$ & 107 & 107 & 79 & 90 \\
\hline \multicolumn{5}{|l|}{ Total } \\
\hline $2 \%$ & 0.07 & $<0.02$ & 5.3 & 7.26 \\
\hline Median & 5.83 & 0.03 & 6.30 & 68.5 \\
\hline Mean & 64.3 & 0.39 & 6.40 & 69.0 \\
\hline SD & 309 & 4.20 & 0.62 & 31.6 \\
\hline $98 \%$ & 553 & 2.14 & 7.9 & 137 \\
\hline Max & 6560 & 133 & 9.00 & 343 \\
\hline$N$ & 2886 & 2885 & 2579 & 2298 \\
\hline
\end{tabular}

${ }^{\mathrm{a}}$ Kruskal-Wallis test, $p=0.00$

${ }^{\mathrm{b}}$ ANOVA, $p=0.00$ 
highest $\mathrm{pH}, 7.0$, was recorded in tube wells $(p=0.00)$. The dissolved oxygen level was highest in springs (median 84.5\%) and lowest in tube wells (38.2\%) $(p=0.00)($ Table 4$)$.

The number of dug wells was multifold compared to the number of other wells. Most water samples from dug wells were derived from shallow wells below $10 \mathrm{~m}$ in depth (Fig. 9). Tube wells were deeper than other Quaternary deposit wells. However, the depth of wells had no clear association with the Mn concentration in single samples of well water from Quaternary deposits $(p=0.065)$.

$\mathrm{Fe}, \mathrm{pH}$, and $\mathrm{O}_{2}$ levels varied significantly between Mn concentration classes. Median Fe concentrations increased concomitantly with $\mathrm{Mn}$ concentrations, being $0.52 \mathrm{mg} / \mathrm{l}$ in the highest class of $\mathrm{Mn},>400$ $\mu \mathrm{g} / \mathrm{l}(p=0.00)($ Table 5), which is above the quality recommendation for household water Fe of $200 \mu \mathrm{g} / \mathrm{l}$ $(0.20 \mathrm{mg} / \mathrm{l})$ in Finland (STM 1352/2015). pH values increased slightly from 6.3, being the highest (6.6) in the two highest Mn classes. Median concentrations of dissolved oxygen decreased from $73.3 \%$ to $27.2 \%$ as Mn concentrations increased $(p=0.00)$ (Table 5).

On average, the highest $\mathrm{Mn}$ and Fe concentrations and $\mathrm{pH}$ levels and the lowest oxygen concentrations were found in tube wells covered by clay. In Finland, especially in the vicinity of the coast, esker areas are covered with clay layers. Deep wells and tubes were dug through these clay layers to reach the sand layer. The oxygen levels are often low and $\mathrm{Fe}$ and $\mathrm{Mn}$ concentrations are high in these types of wells

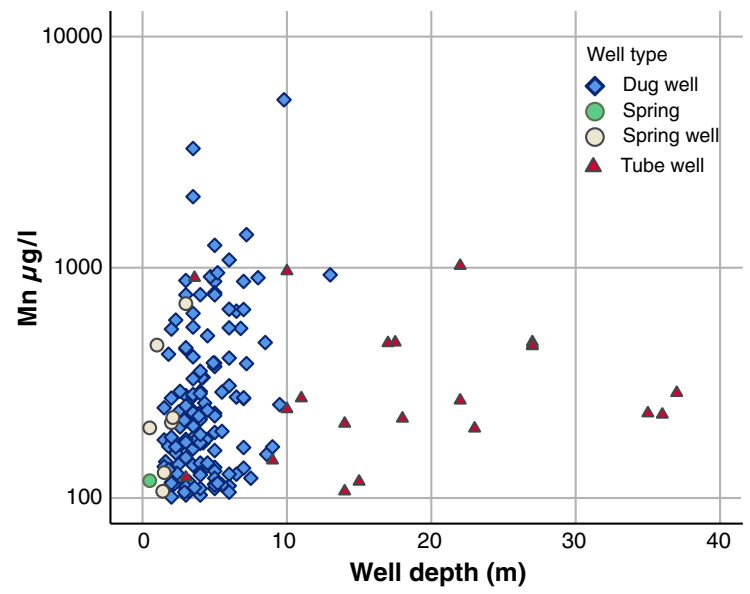

Fig. 9 Manganese concentrations in single samples of water from Quaternary deposits wells ( $\mathrm{Mn}>100 \mu \mathrm{g} / \mathrm{l}$ ) according to depth
Table 5 Median, mean, standard deviation (SD), range, and number of samples $(n)$ for $\mathrm{Fe}, \mathrm{pH}$, and $\mathrm{O}_{2}$ in single samples of Quaternary deposit well water in Finland in 1992-2013 according to categories of Mn concentrations

\begin{tabular}{|c|c|c|c|}
\hline $\mathrm{Mn}$ & $\mathrm{Fe} \mathrm{mg} / \mathrm{l}^{\mathrm{a}}$ & $\mathrm{pH}(\text { field })^{\mathrm{b}}$ & $\mathrm{O}_{2} \%(\text { field })^{\mathrm{a}}$ \\
\hline \multicolumn{4}{|l|}{$<50 \mu \mathrm{g} / 1$} \\
\hline Median & 0.03 & 6.30 & 73.3 \\
\hline Mean & 0.09 & 6.38 & 74.4 \\
\hline SD & 0.29 & 0.61 & 30.07 \\
\hline Range & $<0.03-9.33$ & $3.40-9.0$ & $5.40-343$ \\
\hline$n$ & 2402 & 2150 & 1885 \\
\hline \multicolumn{4}{|c|}{$51-100 \mu \mathrm{g} / 1$} \\
\hline Median & 0.12 & 6.30 & 48.50 \\
\hline Mean & 0.36 & 6.35 & 50.8 \\
\hline SD & 0.55 & 0.63 & 26.4 \\
\hline Range & $<0.03-3.57$ & $4.8-8.1$ & $2.5-131$ \\
\hline$n$ & 162 & 141 & 135 \\
\hline \multicolumn{4}{|c|}{$101-400 \mu \mathrm{g} / 1$} \\
\hline Median & 0.23 & 6.60 & 37.7 \\
\hline Mean & 0.75 & 6.59 & 43.4 \\
\hline SD & 1.44 & 0.64 & 26.3 \\
\hline Range & $<0.03-10.7$ & $5.1-9.0$ & $0-131$ \\
\hline$n$ & 226 & 200 & 194 \\
\hline \multicolumn{4}{|c|}{$>400 \mu \mathrm{g} / 1$} \\
\hline Median & 0.52 & 6.60 & 27.2 \\
\hline Mean & 7.14 & 6.61 & 32.5 \\
\hline $\mathrm{SD}$ & 22.0 & 0.57 & 21.3 \\
\hline Range & $<0.03-133$ & $5.1-7.8$ & $2.5-85.9$ \\
\hline$n$ & 96 & 82 & 78 \\
\hline
\end{tabular}

${ }^{\mathrm{a}}$ Kruskal-Wallis test, $p=0.00$

${ }^{\mathrm{b}}$ ANOVA, $p=0.00$

(Lahermo et al. 2002). Dissolved oxygen levels decreased as a function of increasing Mn concentrations. When the oxygen level in water decreases, several elements of geological origin, including $\mathrm{Mn}$, dissolve in the well water due to the long water retention time. Unexpectedly, $\mathrm{pH}$ was slightly increased concomitantly with $\mathrm{Mn}$ in wells dug in Quaternary deposits. The depth of wells in Quaternary deposits had no significant association with $\mathrm{Mn}$ concentrations.

Mn concentrations were low in spring waters. Spring water, especially in small groundwater catchment areas, resembles rainwater and is therefore low in $\mathrm{Mn}$. The longer retention time of groundwater in 
Quaternary deposits probably causes the release of more elements into the water. Mn dissolution in water was on average higher in wells under anaerobic conditions in clay areas than under aerobic conditions in wells dug in sand deposits. The long retention time of groundwater under a clay bed together with the reducing conditions may increase $\mathrm{Mn}$ dissolution (Lahermo et al. 1990). In general, the highest Mn concentrations in groundwater are found in the western and southwestern coastal areas of Finland, where confining aquifer conditions and dissolved organic material in the water cause oxygen depletion. Consequently, the aquifer type, for instance, the occurrence of peat and fine-grained sediment, the conditions in the well, and pollution are pronounced contributors to the $\mathrm{Mn}$ (and $\mathrm{Fe}$ ) concentrations (Lahermo et al. 1990). In this study, in single water samples from Quaternary deposit wells, high $\mathrm{Mn}$ concentrations were found in coastal areas in the southwestern part of Finland, but also in some wells in northern parts of the country (Fig. 8).

Quaternary deposits: monitoring sites

A total of 4227 analyses from 119 Quaternary deposit wells were included in this study. Only $5.8 \%$ of the water samples exceeded the national quality recommendation of $50 \mu \mathrm{g} / \mathrm{l}$ for $\mathrm{Mn}$. At some monitoring sites, $\mathrm{Mn}$ concentrations in well water remained stable over the years. However, Mn concentrations in well waters from the monitoring sites in the municipalities of Loimaa and Hämeenkoski varied annually, seen as a low gradient curve (Fig. 10). High Mn concentrations, exceeding $100 \mu \mathrm{g} / \mathrm{l}$, were found in water from six Quaternary deposit wells at monitoring sites: five in southern Finland and one in the northern part of the country.

Large annual variation in $\mathrm{Mn}$ concentrations in groundwater between the years 1992 and 2009 was found in Hämeenkoski in southern Finland (Figs. 11 and 12a). Water samples were taken from a 3.3-mdeep dug well with concrete rings (Backman 2004). In general, the minimum $\mathrm{Mn}$ values varied annually between 193-1410 $\mu \mathrm{g} / \mathrm{l}$ in this well water, except in September 1994, when for an unknown reason the minimum Mn concentration was only $8.77 \mu \mathrm{g} / \mathrm{l}$. The maximum concentration varied from $790 \mu \mathrm{g} / \mathrm{l}$ in October 2003 to $2640 \mu \mathrm{g} / \mathrm{l}$ in October 2004 (Fig. 12). The recharge area of this dug well was heavily burdened. The area was characterized by intensive agricultural activity, including a large cowshed, cattle pastures, a greenhouse, and several residential buildings (Backman 2004), and it remains uncertain whether that contributed to Mn levels. The monthly variability in Mn concentrations in water was

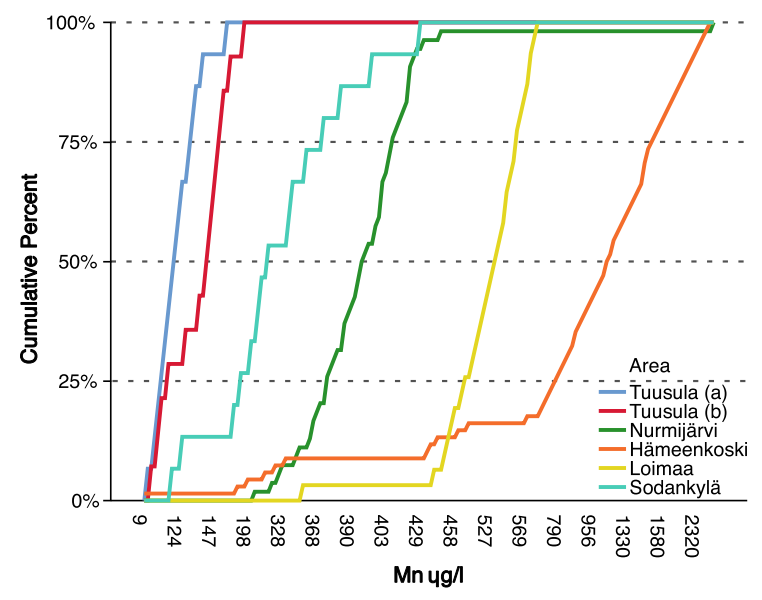

Fig. 10 The cumulative percent distribution of manganese concentrations in water from six Quaternary deposit wells where the $\mathrm{Mn}$ concentration exceeded $100 \mu \mathrm{g} / \mathrm{l}$. The Sodankylä monitoring site is located in northern Finland and the others in the southern part of the country

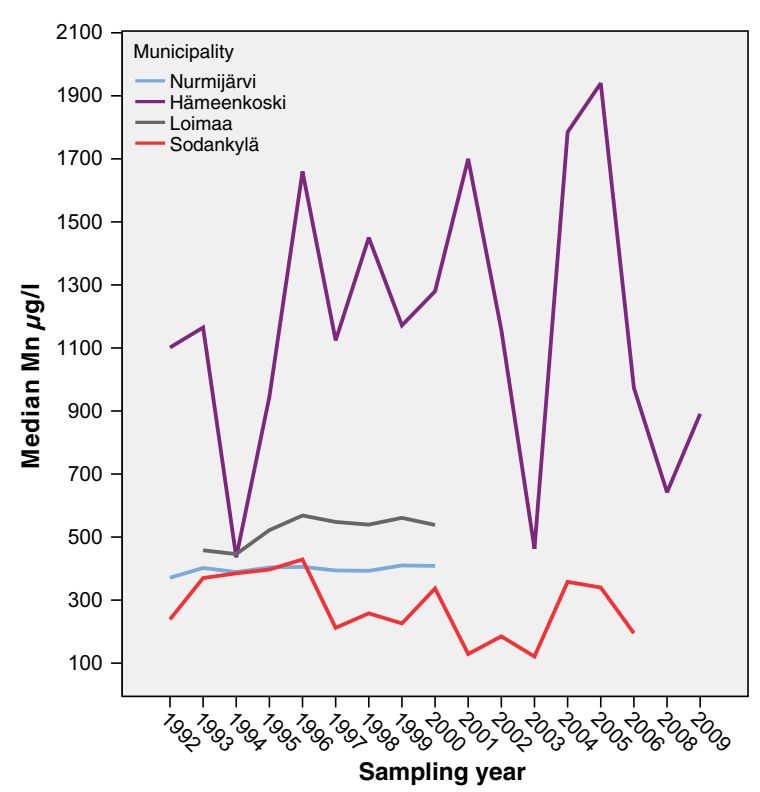

Fig. 11 Annual median Mn concentrations in water from Quaternary deposit wells ( $\mathrm{Mn}>100 \mu \mathrm{g} / \mathrm{l})$ at monitoring sites in 1992-2009 


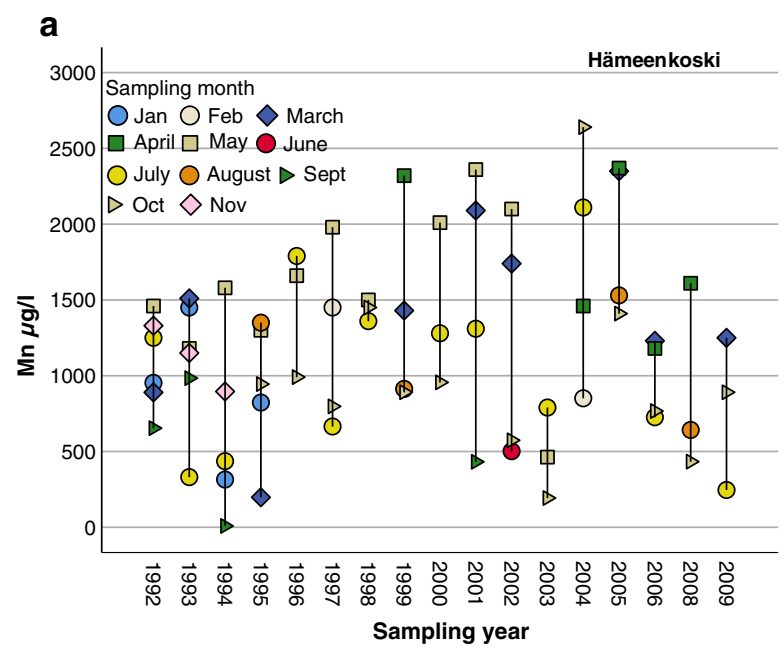

Fig. 12 a Annual and monthly variation in Mn concentrations in dug well water from the Hämeenkoski monitoring site $(\min =8.77 \mu \mathrm{g} / \mathrm{l}, \max =2640 \mu \mathrm{g} / \mathrm{l})$ b Annual variation in $\mathrm{Mn}$

large. The highest concentrations were normally found between March and May. In Nurmijärvi in southern Finland, the Mn concentration in spring water during 1992-2000 varied between $215 \mu \mathrm{g}$ / (Feb 2000) and $438 \mu \mathrm{g} / \mathrm{l}$ (May 1996). The highest concentration, $3750 \mu \mathrm{g} / \mathrm{l}$, was measured in July 2000.

Mn concentrations were probably affected by the $\mathrm{O}_{2}$ levels in the well water (Fig. 12b). When the oxygen level decreased, more Mn dissolved in the well water.

High annual variation in the Mn concentration was found in the dug well at the Enontekiö monitoring site, a municipality in Lapland in the northern part of Finland (Fig. 13). The well was deepened by excavation in 1994, and after this, the quality of the well water substantially changed. The $\mathrm{pH}$ decreased, being 5.0 at the lowest, but the $\mathrm{Mn}$ and Fe concentrations increased, being $1020 \mu \mathrm{g} / \mathrm{l}$ and $1.04 \mathrm{mg} / \mathrm{l}$, respectively. The well probably reached a layer with reducing conditions, or its excavation reached a $\mathrm{Fe}-$ $\mathrm{Mn}$ precipitation layer. A few years later, after excavating the well, the Fe concentration decreased, while the Mn concentration remained at a high level. Erickson et al. (2019) observed that well construction disturbs the aquifer and the geochemical balance of the groundwater and that the resulting geochemical disturbance affects the arsenic concentrations measured

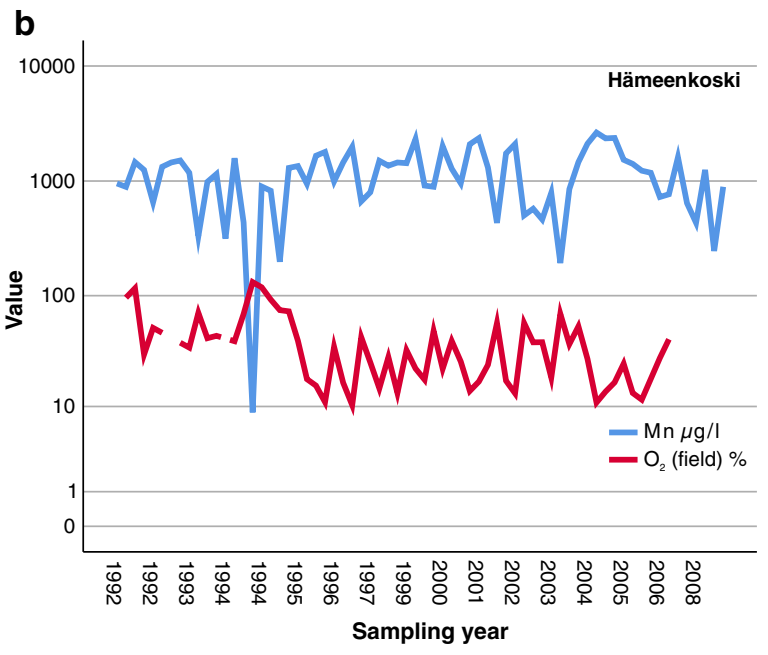

and $\mathrm{O}_{2}$ concentrations in dug well water from the Hämeenkoski monitoring site in 1992-2008

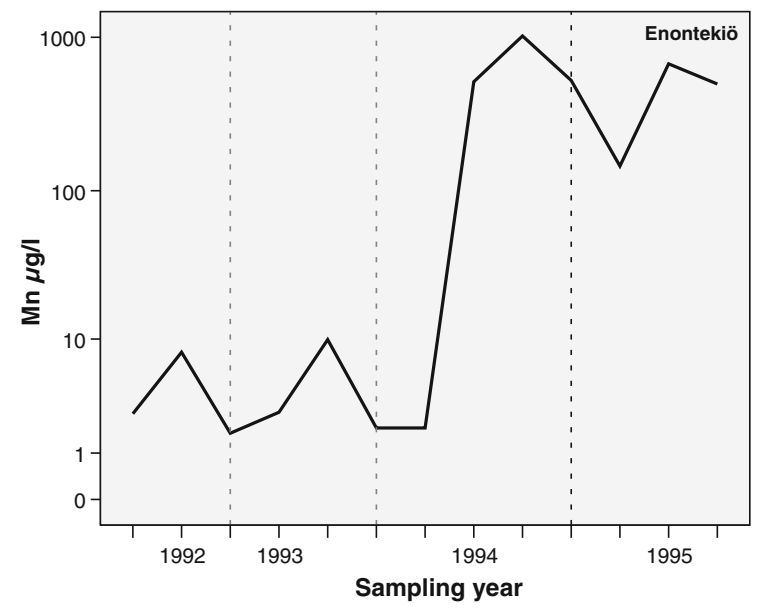

Fig. 13 Annual variation in the Mn concentration in dug well water from a till area at the monitoring site in Enontekiö in 1991-1995

in the wells in northern-central parts of the USA. A similar phenomenon was recorded for Mn concentrations in the dug well in Enontekiö, northern Finland, after the well was excavated to make it deeper.

Mn dissolution in water was on average higher in tube wells located in sandy aquifers covered with clay than under aerobic conditions in wells in sand areas, as shown in Table 6. The retention time of groundwater under a clay bed is long, and conditions are reducing. 
Table 6 Median, mean, standard deviation, maximum, and $2 \%$ and $98 \%$ percentiles for Mn concentrations in well waters from different soils layers at monitoring sites in 1992-2009

\begin{tabular}{llll}
\hline \multicolumn{2}{l}{ Quaternary deposit wells } & & \\
\hline Mn $\mu \mathrm{g} / 1$ & Tube wells covered by sand and clay & Wells in a till area & Wells in a sand area \\
\hline $2 \%$ & 0.03 & 0.05 & 0.04 \\
Median & 1.85 & 0.86 & 0.90 \\
Mean & 49.1 & 34.6 & 14.6 \\
SD & 135 & 180 & 99.1 \\
$98 \%$ & 561 & 714 & 358 \\
Maximum & 583 & 1660 & 3760 \\
$N$ & 437 & 1135 & 2248 \\
\hline
\end{tabular}

In wells with under $100 \mu \mathrm{g} / \mathrm{l} \mathrm{Mn}$, the variability was smaller. The largest variation in this group was in a dug well in Inari, in which the minimum was $0.97 \mu \mathrm{g} / \mathrm{l}$ (Aug 2003) and the maximum $97.40 \mu \mathrm{g} / \mathrm{l}$ (March 1994).

Total manganese and soluble manganese

The soluble form of Mn was typically analyzed in groundwater studies conducted by GTK. Experimental paired analyses for total $\mathrm{Mn}$ and soluble Mn were conducted separately from 31 samples, comprising 11 samples from drilled wells and 20 samples from Quaternary deposit wells (Fig. 14). The findings from these analyses indicated that in most samples, the total $\mathrm{Mn}$ concentration was higher than the soluble $\mathrm{Mn}$ concentration, suggesting that $\mathrm{Mn}$ in water was also partly in a particle-bound form. Mn only existed in a purely soluble form in a few wells. The median proportion of soluble Mn was $81.8 \%$ in drilled well waters and $56.0 \%$ in Quaternary deposit well waters, but the variation was high (Table 7). For wells dug in Quaternary deposits, the water samples were mostly taken directly from the water source, not from a tap. Thus, Mn was already particle bound in the well. If a water sample is taken from a tap, Mn may additionally bind to particles in the water piping system. The notable difference between soluble and total $\mathrm{Mn}$ concentrations suggests that to obtain the overall $\mathrm{Mn}$ status of the well water, measurement of both soluble $\mathrm{Mn}$ and total $\mathrm{Mn}$ is preferable.

The present data confirm previous findings (Lahermo et al. 1990; Karppinen et al. 2012) and indicate that $\mathrm{Mn}$ concentrations are higher in water from

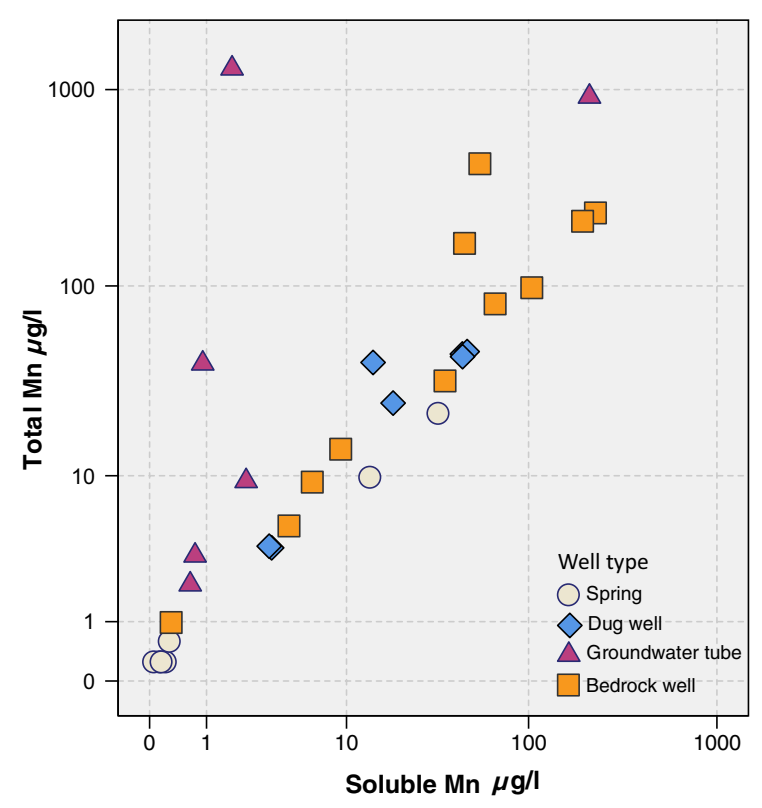

Fig. 14 Total $\mathrm{Mn}(\mu \mathrm{g} / \mathrm{l})$ concentrations in relation to soluble $\mathrm{Mn}(\mu \mathrm{g} / \mathrm{l})$ in groundwater according to the water source in 2005-2013 $(n=31)$

private bedrock wells than in Quaternary wells, and high concentrations are rather common in Finland. Similar observations for well waters have been made elsewhere. For example, in Scotland, elevated $\mathrm{Mn}$ concentrations, $>50 \mu \mathrm{g} / \mathrm{l}$, were detected in $30 \%$ of 475 groundwater sampling sites (Homonick et al. 2010). In $9 \%$ of the water samples analyzed in this study, the Mn concentration exceeded $400 \mu \mathrm{g} / \mathrm{l}$. For comparison, in Bangladesh the median Mn concentration has been as high as $734 \mu \mathrm{g} / \mathrm{l}$ in wells over $50 \mathrm{~m}$ deep, and $126 \mu \mathrm{g} / \mathrm{l}$ in shallow wells below $50 \mathrm{~m}$ in depth (Rahman et al., 2017). 
Table 7 Soluble and total Mn concentrations, and median, minimum and maximum content in single samples of water from Quaternary deposit wells and bedrock wells in 2005-2013
${ }^{\text {a According to }}$ laboratory: $>100 \%$ is due to inaccuracy and uncertainty of measurements

\begin{tabular}{|c|c|c|c|}
\hline & Mn $\mu \mathrm{g} / 1$, soluble & $\mathrm{Mn} \mu \mathrm{g} / \mathrm{l}$, total & Mn soluble $/ \mathrm{Mn}$, total $\%$ \\
\hline \multicolumn{4}{|l|}{ Drilled wells } \\
\hline 1 & 45.3 & 165 & 27.5 \\
\hline 2 & 9.3 & 14.0 & 66.1 \\
\hline 3 & 54.8 & 420 & 13.0 \\
\hline 4 & 227 & 236 & 96.2 \\
\hline 5 & 35.5 & 32.3 & $>100^{\mathrm{a}}$ \\
\hline 6 & 0.30 & 0.98 & 30.6 \\
\hline 7 & 4.46 & 5.1 & 87.1 \\
\hline 8 & 104 & 97.9 & $>100^{\mathrm{a}}$ \\
\hline 9 & 66.2 & 80.9 & 81.8 \\
\hline 10 & 6.3 & 9.2 & 67.9 \\
\hline 11 & 194 & 214 & 90.7 \\
\hline Total $N$ & 11 & 11 & \\
\hline Median & 45.3 & 80.9 & 81.8 \\
\hline Minimum & 0.30 & 0.98 & 13.0 \\
\hline Maximum & 227 & 420 & $>100^{\mathrm{a}}$ \\
\hline \multicolumn{4}{|c|}{ Quaternary deposit wells } \\
\hline 1 & 1.7 & 1280 & 0.1 \\
\hline 2 & 0.74 & 3.3 & 22.2 \\
\hline 3 & 14.2 & 40.3 & 35.2 \\
\hline 4 & 0.27 & 0.59 & 45.8 \\
\hline 5 & 0.91 & 39.8 & 2.3 \\
\hline 6 & 0.21 & 0.25 & 84.0 \\
\hline 7 & 2.24 & 9.3 & 24.0 \\
\hline 8 & 18.4 & 24.7 & 74.5 \\
\hline 9 & 0.15 & 0.25 & 60.0 \\
\hline 10 & 3.3 & 3.8 & 86.9 \\
\hline 11 & 0.64 & 2.1 & 30.6 \\
\hline 12 & 3.4 & 3.7 & 91.4 \\
\hline 13 & 46.8 & 45.9 & $>100^{\mathrm{a}}$ \\
\hline 14 & 13.6 & 9.8 & $>100^{\mathrm{a}}$ \\
\hline 15 & 44.1 & 44.6 & 98.9 \\
\hline 16 & 44.2 & 43.2 & $>100^{\mathrm{a}}$ \\
\hline 17 & 211 & 921 & 22.9 \\
\hline 18 & 32.5 & 21.8 & $>100^{\mathrm{a}}$ \\
\hline 19 & 0.13 & 0.25 & 52.0 \\
\hline 20 & 0.05 & 0.25 & 20.0 \\
\hline Total $N$ & 20 & 20 & \\
\hline Median & 2.8 & 9.6 & 56.0 \\
\hline Minimum & 0.05 & 0.25 & 0.1 \\
\hline Maximum & 211 & 1280 & $>100^{\mathrm{a}}$ \\
\hline
\end{tabular}




\section{Summary and conclusions}

The association of geochemical factors with the natural concentrations of $\mathrm{Mn}$ in groundwater was investigated. High $\mathrm{Mn}$ concentrations were more common in waters in wells drilled in bedrock than well waters in Quaternary deposits. Among single samples, low dissolved oxygen content associated with high Mn concentrations and elevated Mn with elevated Fe concentration. No clear association was observed between the $\mathrm{Mn}$ concentration and $\mathrm{pH}$ or depth of wells in single water samples from wells in bedrock or Quaternary deposits.

Among monitoring wells in both bedrock and Quaternary deposits, two different types of wells were found in relation to the $\mathrm{Mn}$ concentrations in water: Mn concentrations were stable in the majority of wells, but in addition there were also wells with high variability in Mn concentrations, especially in Quaternary deposits. The Mn concentration did not depend on depth of the well. The annual or seasonal variability in $\mathrm{Mn}$ concentrations in well water with high $\mathrm{Mn}$ concentrations (>100 $\mu \mathrm{g} / \mathrm{l} \mathrm{Mn}$ ) was large. High Mn concentrations were more often detectable in the water of bedrock wells than in Quaternary deposit wells. Seasonal variation in $\mathrm{Mn}$ concentrations was not common in bedrock wells, but was nevertheless detectable in two wells at monitoring sites.

The total Mn concentration was generally higher than the soluble Mn concentration when both were measured, suggesting that Mn was partly bound to particles in the water, and the relationship between the total and soluble concentrations varied. Thus, the analysis of soluble Mn alone may not always reveal the actual Mn status of the well water. Furthermore, single measurements may not reveal the true Mn status of the well water, and repeated measurements of both soluble and total Mn may be preferable.

The number of wells at monitoring sites was relatively small, and they were located in certain small areas of Finland. Therefore, it is not as yet possible to state how common this variation is. The results are tentative, and a larger number of wells need to be examined to confirm the proportion of wells with high variation in the Mn level.

Acknowledgements This project was supported by a grant from the Erkki Paasikivi Foundation, the Geological Survey of
Finland, the National Institute for Health and Welfare, and the University of Eastern Finland.

Open Access This article is licensed under a Creative Commons Attribution 4.0 International License, which permits use, sharing, adaptation, distribution and reproduction in any medium or format, as long as you give appropriate credit to the original author(s) and the source, provide a link to the Creative Commons licence, and indicate if changes were made. The images or other third party material in this article are included in the article's Creative Commons licence, unless indicated otherwise in a credit line to the material. If material is not included in the article's Creative Commons licence and your intended use is not permitted by statutory regulation or exceeds the permitted use, you will need to obtain permission directly from the copyright holder. To view a copy of this licence, visit http://creativecommons.org/licenses/by/4.0/.

\section{References}

Ander, E. L., Watts, M. J., Smedley, P. L., Hamilton, E. M., Close, R., Crabbe, H., et al. (2016). Variability in the chemistry of private drinking water supplies and the impact of domestic treatment systems on water quality. Environmental geochemistry and health, 38(6), 1313-1332. https:// doi.org/10.1007/s10653-016-9798-0.

Agency for Toxic Substances and Disease Registry (ATSDR). 2012. Toxicological Profile for Manganese. Atlanta, GA: U.S. Department of Health and Human Services, Public Health Services. https://www.atsdr.cdc.gov/substances/ toxsubstance. asp?toxid=23 (Last reviewed and updated August 14, 2018, accessed 28.2.2019)

Backman, B. (1993). Lammin-Kosken (HI) alueen pohjaveden seurantatutkimus. Vuosien 1969-1990 tulokset. Summary: Groundwater monitoring in the Lammi-Koski area, results for 1969-1990. Geological Survey of Finland, Report of Investigation, 118. Espoo. (p. 100) https://tupa.gtk.fi/ julkaisu/tutkimusraportti/tr_118.pdf. (accessed 1.7.2020)

Backman, B., Lahermo, P., Väisänen, U., Paukola, T., Juntunen, R., Karhu, J.,et al. (1999). Geologian ja ihmisen toiminnan vaikutus pohjaveteen: seurantatutkimuksen tulokset vuosilta 1969-1996 (in Finnish). Summary: The Effect of Geological Environment and Human Activities on Groundwater in Finland. The Results of Monitoring in 1969 - 1996. Geological Survey of Finland. Report of Investigation, 147. ISSN 0781-4240. Espoo, (p. 261).

Backman, B. (2004). Groundwater quality, acidification, and recovery trends between 1969 and 2002 in South Finland. Geological Survey of Finland, Bulletin. Espoo. Academic dissertation. ISBN: 951-690-895-0. (p. 110).

Backman, B., Luoma, S., Ruskeeniemi, T., Karttunen, V., Talikka, M. \& Kaija, J. (2006). Natural Occurrence of Arsenic in the Pirkanmaa region of Finland. Geological Survey of Finland, Miscellaneous Publications, (p. 88). https://tupa.gtk.fi/julkaisu/erikoisjulkaisu/ej_057.pdf. (accessed 1.7.2020) 
Bedrock of Finland-DigiKP. (2019) Digital map database [Electronic resource]. Espoo: Geological Survey of Finland [referred 17.07.2019]. Version 2.1.

Bouchard, M. F., Sauvé, S., Barbeau, B., Legrand, M., Brodeur, M.-E., Bouffard, T., et al. (2011). Intellectual impairment in school-age children exposed to manganese from drinking water. Environmental Health Perspectives, 119(1), 138-143. https://doi.org/10.1289/ehp.1002321.

Erickson, M. L., Malenda, H. F., Berquist, E. C., \& Ayotte, J. D. (2019). Arsenic concentrations after drinking water well installation: Time-varying effects on arsenic mobilization. Science of the Total Environment, 678, 681-691. https:// doi.org/10.1016/j.scitotenv.2019.04.362.

Hatakka, T. \& Väisänen, U. (2007). The Effect of the Geological Environment and Human Activities on Groundwater in Finland. The Results of Monitoring to 2004. Geologian tutkimuskeskus, Tutkimusraportti-Geological Survey of Finland, Report of Investigation 165. (p. 230) https://tupa. gtk.fi/julkaisu/tutkimusraportti/tr_165.pdf.

(accessed 1.7.2020)

Health Canada. 2019. Guidelines for Canadian Drinking Water Quality: Guideline Technical Document-Manganese. (p. 107). www.canada.ca/en/health-canada/services/environ mental-workplace-health/reports-publications/water-quality. html. (accessed 14.4.2020)

Homoncik, S. C., Macdonald, A. M., Heal, K. V., Dochartaigh, B. E., \& Ngwenya, B. T. (2010). Manganese concentrations in Scottish groundwater. Science of the Total Environment., 408(12), 2467-2473. https://doi.org/10.1016/j. scitotenv.2010.02.017.

International Manganese Institute. IMnI. (2013). Manganese in groundwater: Research and potential risks. International Manganese Institute. Fact sheet 6.https://cn.manganese. org/images/uploads/pdf/Manganese_Fact_Sheet_6_HR. pdf

Johnson, C. D., Nandi, A., Joyner, T. A., \& Luffman, I. (2018). Iron and manganese in groundwater: Using Kriging and GIS to locate high concentrations in buncombe county. North Carolina Ground Water, 56(1), 87-95. https://doi. org/10.1111/gwat.12560.

Karppinen, H., Komulainen, H., Kousa, A., Nikkarinen, M., Tornivaara, A. (2012). Haitalliset alkuaineet Kainuun kaivovesissä-hanke 2/2011-12/2012. In Finnish. Kainuun maakunta-kuntayhtymä. ISSN 1795-5661. Kajaani. https://urn.fi/URN:NBN:fi-fe201312027490.. (accessed 1.7.2020)

Khan, K., Factor-Litvak, P., Wasserman, G. A., Liu, X., Ahmed, E., Parvez, F., et al. (2011). Manganese exposure from drinking water and children's classroom behavior in Bangladesh. Environmental Health Perspectives, 119(10), 1501-1506.

Koljonen, T., \& Tanskanen, H. (1992). Quaternary sediments. In T. Koljonen (Ed.), The Geochemical Atlas of Finland, Part 2: Till (p. 218). Espoo: Geological Survey of Finland.

Korkka-Niemi, K. (2001). Cumulative geological, regional and site-specific factors affecting groundwater quality in domestic wells in Finland Monographs of the Boreal Environmental Research 20 (p. 98). Finland, Helsinki: Finnish Environmental Institute.

Kortelainen, N. M., \& Karhu, J. A. (2004). Regional and seasonal trends in the oxygen and hydrogen isotope ratios of
Finnish groundwaters: A key for mean annual precipitation. Journal of Hydrology, 285(1-4), 143-157. https://doi. org/10.1016/j.jhydrol.2003.08.014.

Kousa, A., Backman, B., Komulainen, H. \& Hartikainen, S. (2017). Kaivoveden mangaani-KAIMA-projekti. In Finnish. Archive Report 95/2016. Geologian tutkimuskeskus. https://tupa.gtk.fi/raportti/arkisto/95_2016.pdf

Lahermo, P., Ilmasti, M., Juntunen, R., \& Taka, M. (1990). The hydrogeochemical mapping of Finnish groundwater The Geochemical Atlas of Finland Part. Espoo: Geological Survey of Finland.

Lahermo, P., Tarvainen, T., Hatakka, T., Backman, B., Juntunen, R., Kortelainen, N., et al. (2002). Tuhat kaivoaSuomen kaivovesien fysikaalis-kemiallinen laatu vuonna 1999 (in Finnish). Summary: One thousand wells-the physical-chemical quality of Finnish well waters in 1999. Report of Investigation 155. Geological Survey of Finland. Espoo. https://urn.fi/URN:NBN:fi-fe2014120247956

Neal, A. P., \& Guilarte, T. R. (2013). Mechanisms of lead and manganese neurotoxicity. Toxicol. Res., 2, 99-114.

Oulhote, Y., Mergler, D., Barbeau, B., Bellinger, D. C., Bouffard, T., Brodeur, M. E., et al. (2014). Neurobehavioral function in school-age children exposed to manganese in drinking water. Environmental Health Perspectives, 122, 1343-1350. https://doi.org/10.1289/ehp.1307918.

Nironen, M., Kousa, J., Luukas, J., Lahtinen, R. (eds) 2016. Geological Map of Finland: Bedrock 1:1 000 000. Second edition. Special Maps, 97 ISBN: 978-952-217-334-8; 978-952-217-335-5 (PDF). Geological Survey of Finland.

Rahman, S. M., Kippler, M., Tofai, 1 F, Bölte, S., Hamadani, J. D., \& Vahter, M. (2017). Manganese in drinking water and cognitive abilities and behavior at 10 years of age: A prospective cohort study. Environmental Health Perspectives, 26, 125.

Simpson, H. (2015). Ground Water-An Important Rural Resource, Private Rural Water Supplies. Factsheet 15-047. Modified May 14, 2019. Ministry of Agriculture, Food and Rural Affair.https://www.omafra.gov.on.ca/english/ engineer/facts/15-047.htm\#2. (accessed 22.11.2019)

Smith, EA., Newland, P., Bestwick, KG., Ahmed, N. (2013). Increased whole blood manganese concentrations observed in children with iron deficiency anaemia. Journal of trace elements in medicine and biology: Organ of the Society for Minerals and Trace Elements, 27:65-69 https://www. sciencedirect.com/science/article/pii/ S0946672X12001125

STM (2001). Decree of the Ministry of Social Affairs and Health on the quality requirements and control examinations of drinking water in small units (401/2001). The Ministry of Social Affairs and Health.

STM (2015). The Decree of the Ministry of Social Affairs and Health relating to the quality and monitoring of water Intended for human consumption (1352/2015). The Ministry of Social Affairs and Health.

Tarvainen, T., Lahermo, P., Hatakka, T., Huikuri, P., Ilmasti, M., Juntunen, R., Karhu, J., Kortelainen, N., Nikkarinen, M., Väisänen, U. (2001). Chemical composition of well water in Finland - main results of the "One thousand wells" project. In Autio. S (ed.) Geological Survey of Finland, Current Research 1999-2000, Special Paper 31, 
57-76. https://tupa.gtk.fi/julkaisu/specialpaper/sp_031. pdf. (accessed 1.7.2020)

Wasserman, G. A., Liu, X., Parvez, F., Factor-Litvak, P., Ahsan, H., Levyet, D., et al. (2011). Arsenic and manganese exposure and children's intellectual function. Neurotoxicology, 32(4), 450-457. https://doi.org/10.1016/j.neuro. 2011.03.009.

WHO. (2011). Guidelines for drinking-water quality - 4th ed. 2011. WHO Library Cataloguing-in-Publication Data. Geneva. Switzerland. https://www.who.int/water_ sanitation_health/publications/dwq-guidelines-4/en/. (accessed 1.7.2020)
WHO. (2017). Guidelines for drinking-water Quality: Fourth Edition Incorporating the First Addendum Geneva: World Health Organization. ISBN:13: 978-92-4-154995-0 https:// www.who.int/water_sanitation_health/publications/drink ing-water-quality-guidelines-4-including-1st-addendum/ en/. (accessed 1.7.2020)

Publisher's Note Springer Nature remains neutral with regard to jurisdictional claims in published maps and institutional affiliations. 